\title{
Co-creating knowledge in tourism research using the Ketso method
}

Tourism scholars have called for critical engagement with transformational cocreative methodologies (see Dredge and Phi (2018); Pritchard, Morgan, and Ateljevic (2011). Within this call, there is a need for researchers to be positioned as facilitators and co-creators rather than lone experts. We provide a critical review of the Ketso method. Ketso is a facilitated 'workshop in a bag'; a toolkit that enables people to think and work together. Ketso can be used for data collection and as a supplementary analysis tool. Critical reflections on Ketso are provided to illustrate how it co-creates knowledge and collaborative solutions for transformational tourism. As a data collection tool, Ketso provides an innovative and authentic approach to stakeholder collaboration and decision making. As a supplementary data analysis tool, it provides an opportunity to address some of the limitations of thematic analysis such as simplicity and lack of coherence. The empirical material came from the New Zealand Tourism For All project and a study on host-guest relationships in a volunteer programme. We critically discuss the ability of Ketso to overcome the rationalistic, logo-centric tendencies of verbal research methods to enable participants to communicate more effectively. In providing critical reflections on Ketso, we contribute to future thinking for the adoption of this co-creative method for tourism research.

Keywords: Ketso; creative methodology; transformational tourism; stakeholder collaboration; participation; co-creation. 


\section{Introduction}

Tourism scholars have called for a critical engagement with transformational research methodologies as they noted that tourism still seems enamoured with traditional methods of enquiry which continue to reproduce existing knowledge, activities and language practices (Gillovic, McIntosh, Darcy, \& Cockburn-Wootten, 2018, p. 23; Sedgley, Pritchard, \& Morgan, 2011). Tourism researchers have commented that "[d]espite this mass of research ...we are failing to answer questions", calling for scholars to think creatively to problems, critique assumptions, analyse rhetoric and evaluate the broader power discourses to gain a deeper understanding of relationships (Singh, 2012, p. 23). To address this failure, critical researchers have advocated for methodological activities that move beyond the 'academic as epidemic' approach to, instead, adopting collaborative frameworks that disrupt these traditional methodological and academic assumptions in the field (Cockburn-Wootten, McIntosh, Smith, \& Jefferies, 2018; Ramanayake, McIntosh, \& Cockburn-Wootten, 2018; Rydzik, Pritchard, Morgan, \& Sedgley, 2013; Scarles, 2010). As critical tourism researchers, we have sought to adopt methods that foster creative approaches, develop tactics for reciprocal knowledge transfer and to encourage ourselves and "our students to think against the grain" (Singh, 2012, p. 23). Our paper seeks to contribute to this gap by offering a consideration of a research method, Ketso, that we employed to foster creative and reciprocal knowledge transfer between researchers and the stakeholders aiming to make a difference to our communities.

Recently, there has been interest around developing research practices that make an impact and bridge academia, local communities and society. Academics and industry participants, for example, have discussed ways around how to increase research impact to provide benefits to stakeholders outside of academia (Boaz, Fitzpatrick, \& Shaw, 
2009; Hill, 2016; Reed, 2018). These relationships, illustrate the reality of working within contexts with differing interpretations, sense-making, dynamics, messiness and calls for researchers to consider "tools and methods that enhance our understandings complex government-business-civil-society relations" (Dredge, 2006, p. 564). Nowotny, Scott, and Gibbons (2003) note that this approach shifts the research focus and dissemination from the 'old paradigm of scientific discovery' to a 'new paradigm of knowledge production' focusing on knowledge distribution, transdisciplinary application-oriented research and considerations of multiple accountabilities (p. 179). This perspective calls for academics to position researchers and participants as facilitators and co-creators, rather than 'lone experts' engaged in top-down and one-way communication (Cockburn-Wootten et al., 2018).

Scholars, for example, Galvagno and Dalli (2014), Greenhalgh, Jackson, Shaw, and Janamian (2016) and Campos, Mendes, Valle, and Scott (2018) have presented systematic reviews of the literature on co-creation. As a concept prevalent in the management, psychology, education, planning and development literature, it focuses on creating value (both materially and symbolically) through interaction for collaborative knowledge generation and the development of new opportunities. Co-creation is a concept increasingly being used by academics as an approach to align research with an understanding and engagement with end users. As a method, it focuses on civic engagement, power sharing, intersectional collaboration, processes, relationships and conflict management. It is seen as an approach to achieve research impact; to move "beyond the ivory towers" to deliver social impact (Greenhalgh et al., 2016, p. 392). To illustrate this approach, we provide a critical review of the Ketso method for co-creating tourism knowledge. Ketso is a portable toolkit, or 'workshop in a bag', that enables people to think and work together more productively in a facilitated environment. Our 
twofold critical reflections on Ketso provide an overview of the Ketso toolkit as a method of data collection to co-create solutions for accessible tourism through stakeholder engagement and as a supplementary data analysis tool used in our tourism research.

\section{Moving from traditional methods to co-creative disruption}

Methodologies provide a framework for the philosophical approach used within research and shape how the researcher uses data collection tools. It is this theoretical approach that drives the design and handling of the data collection tools. For instance, two researchers can both employ interviews in their studies, but how they design the procedures, questions, relationship with participants, ethical considerations and analysis techniques will all vary depending on their philosophical premise.

Within the wider academia, scholars have critiqued research designs for their “cookie cutter" approach in which the same designs are repetitively and narrowly applied in ways that limit what is studied and how it is studied" (Harwell, 2011, p. 147). Across disciplines, similar constraints with traditional research tools have been identified. For example, consumer research scholars Zaltman and Coulter (1995) noted that traditional research techniques still limit the experiences and participation of the participant due to the dominance of written and verbal responses; "survey research and in most qualitative techniques is verbo-centric" (p. 36). Within health, researchers have noted that despite the multitude of research studies on trying to change health outcomes for communities, very little change has actually occurred in the communities facing those health issues (Horowitz, Robinson, \& Seifer, 2009). Instead, health researchers have realised that it is crucial to include participants in the research design process to increase self-efficacy and mutual learning around the issue. 
Traditional research techniques are also limiting for sustainability and environmental disciplines due to the complex problems encountered within this sector. Sustainability scholars require tools that overcome problems, in an ambiguous context, with an overall desire to vision new solutions and possibilities (Dale \& Newman, 2005; Haseman, 2006). Similarly, sustainability and tourism scholars have also argued for a reorientation to include research tools that value social relations, appreciate the diversity of context and enhance active involvement in the study design for research participants (Cockburn-Wootten et al., 2018; Dredge, 2006; Potts \& Harrill, 1998). In response to these limitations, scholars have sought to employ and encourage consideration of designs and tools that challenge orthodox enquiry.

Participatory approaches to engage diverse stakeholders have been seen as a more equitable way to conduct research, address the issue or need facing the community, develop mutual learning and gain social change (Cockburn-Wootten et al., 2018). This framework moves away from seeking one truth to trying to understand how issues are "socially constructed, therefore that it is subject to reinterpretation, revision and enrichment" and is concerned with praxis and transformation (Fals Borda, 2001, p. 31). In seeking this change, researchers are concerned with the theoretical orientation of the research and how to create participation. This framework challenges traditional considerations around the concept of expertise and participation, i.e. who can know and make decisions about the topic under scrutiny in the project (Bean \& Baber, 2011). To facilitate this approach, creative participatory methods are employed to stimulate dialogue, develop understandings that transcend verbal and written language descriptors, aiming to create transformation and change solutions, especially for complex issues facing diverse communities. 
Creative participatory methods are defined as context-specific and "challenge dominant assumptions and conventions around what constitutes research, knowledge and impact" (van der Vaart, van Hoven, \& Huigen, 2018, p. 6). In challenging dominant assumptions, creative and participatory methods open up new understandings and can reveal emotional responses too. Examples show that the use of creative participatory methods allows dialogue, helps identify the problem or barriers, indicates different interpretations of an issue and deeper understandings of experiences that may be emotional or difficult to describe. Photovoice, for instance, enables participants to discuss experiences that are sensitive, emotional and topics that cannot be captured or labelled. Baker and Wang (2006) study examining chronic pain concluded that this research tool developed self-efficacy to communicate the experience of chronic pain. Another example, LEGO® SERIOUS PLAY®, aims to encourage dialogue and solutions through the use of models built by participants. It heavily draws on concepts of play, the use of metaphors, flow and constructivism (Wengel, McIntosh, \& Cockburn-Wootten, 2016).

Creative participatory approaches differ from the mainstream tools because they do not rely on written or verbal responses, foreground accountability, involvement and mutual learning of individuals that experience and are involved in the research issue. These types of studies are not researcher led or dominated; instead, they are designed, to begin with the participants identifying and prioritising the issues that they see as important to their communities. This approach aims to develop inductive dialogic communication processes to "create space[s] for the dynamic interchange of knowledge and understandings" through "a shared commitment to understanding issues and processes ... to construct new ways of conceptualising practice" (Cook, Atkin, \& Wilcockson, 2017, p. 1). Working with communities and ensuring that dissemination of 
mutual knowledge and learning outcomes are crucial for this methodological research design.

Within tourism studies, there has been a recent move to design research that considers the role of researchers and participants as co-creators of knowledge outcomes. The premise framing this approach is a desire to adopt methods that decentralise power, foster creative thinking and develop knowledge transfer and dissemination. This framework draws on a variety of critical theoretical approaches within tourism, such as hopeful tourism, feminist, indigenous to social justice approaches to research design (Canosa, Wilson, \& Graham, 2017; Hales, Dredge, Higgins-Desbiolles, \& Jamal, 2018; Pritchard et al., 2011). A table below provides a summary of creative participatory methods used in tourism research (Barry, 2017; Ji \& King, 2018; Ren et al., 2010; Rydzik et al., 2013; Salazar, 2012; Wengel et al., 2016; Willson et al., 2013).

[Insert Table 1 near here.]

Caption: Table 1 Creative participatory methods. Source: Authors.

Participants involved in creative participatory approaches to research report enjoyment during the process highlighting that creative participatory methods allow time to reflect on their personal experiences and greater focus on 'doing' activities, hence, producing richer context than question and answer interviews (Banks, 2007; Pink, 2012). Yet, despite the advantages "visual research methods... remain[s] reasonably marginal within an existing qualitative practice" with the prevalence of traditional qualitative approaches (Gauntlett \& Awah, 2012, p. 590). The majority of this work aims to start with an inductive, emic approach endeavouring to include selfefficacy, dialogue and "admit the possibility of the existence of other visions of the world where nature, spirituality and human relationships play a leading role in shaping the conformation of knowledge" (Espeso-Molinero, Carlisle, \& Pastor-Alfonso, 2016, 
p. 1334). With this in mind, we present a discussion of Ketso, a creative participatory tool.

\section{The philosophy and process of Ketso}

Ketso is a toolkit which enables people to think and work together more productively (Tippett, 2013; Tippett \& How, 2011). The philosophy behind the method embraces principles of participatory research grounded on co-creational practices in order to give (marginalised) participants individual voice to create an impact on the project for the wider community. As a participatory action research tool within the social sciences (Tippett, Handley, \& Ravetz, 2007), the technique draws on theories of creative thinking (De Bono, 2009), mind mapping (Buzan \& Buzan, 2006), experiential learning (Kolb, 1984), and multiple intelligences (Gardner, 1999). Originating from the disciplines of education and environmental studies, Ketso has now been used in various disciplines to create engagement, co-learning and collaborative thinking (Bates, 2016). In one study on organisational change in academic libraries, for instance, Ketso was used as a tool to develop research questions and for mapping change within libraries spaces (Whitworth, Torras I Calvo, Moss, Amlesom Kifle, \& Blåsternes, 2014). In their research, participants took part in six Ketso workshops adopting mapping techniques to identify changes in their workplace. During the workshops, participants followed the steps of Ketso method to discuss their current working situation, information needed in order to complete work tasks, sources of information and challenges of acquiring this information. At the end of the workshop, participants prioritised future actions which were revisited during later workshops. Data obtained during these Ketso sessions allowed broad comparisons of the organisational changes in the workplace environment. Internationally, Ketso is now used on six continents around the world, and workshop themes have included community-led planning and regeneration, engaging stakeholders 
on behalf of local and government agencies, corporate training, developing new businesses, team building, student-led learning, and providing tools for teachers and researchers (Tippett \& How, 2011).

In tourism studies, Ketso is still relatively new and underexplored. McIntosh and Cockburn-Wootten (2016) have used Ketso as a qualitative data collection tool for engaged, participatory tourism scholarship with a variety of diverse participants to address social issues. They argue that Ketso offers a creative way for tourism researchers to become facilitators in co-creating insightful outcomes with tourism stakeholders and the wider community. Furthermore, Ketso was used to understand the concept of community hospitality and how this type of hospitality is employed by refugee-service organisations in facilitating welcome to refugees to New Zealand (McIntosh \& Cockburn-Wootten, 2018). In another study, Cockburn-Wootten et al. (2018) discuss and illustrate how these type of creative tools can provide new possibilities for practice, knowledge and crossing traditional tourism stakeholder silos. They conclude by arguing that orientating research studies within a participatory creative framework by using tools such as Ketso, enables us to challenge dominant assumptions, create reciprocal learning opportunities and make a difference to our communities.

As a facilitated workshop technique, Ketso represents an inclusive tool which helps to unleash participants' creativity. Inclusive research denotes tools and activities that involve people beyond their traditional role in mainstream research as a 'subject'. These activities and roles can encompass a broad range of involvement to include framing research questions, providing the right to access information, leadership roles with the study to involvement in the data analysis (Bigby, Frawley, \& Ramcharan, 2014). Ketso enables many of these participatory, inclusive activities to happen by 
promoting critical dialogue to identify the key issues, possible collaborative solutions and develops a reciprocal knowledge space through individuals thinking through issues together. To illustrate how these activities occur through Ketso, we begin by describing the toolkit and process of Ketso.

A standard Ketso kit accommodates up to 24 participants, and consists of a large felt mat, grid mat, coloured plastic cards ('leaves') and icons, felt stripes ('branches'), marking pens with water-soluble ink, and the guide (www.ketso.com). The leaves, branches, and icons are movable and attach to felt with Velcro. The kit (Figure 1) is sustainable; all items are reusable, colourful, and tactile. As an accessible, inclusive tool, Ketso could be used with illiterate participants who can make drawings on leaves and with colour-blind participants who can determine the colour of the leaf from the designated letter at the corner of each leaf.

[Insert Figure 1 near here.]

Caption: Figure 1 Ketso Kit. Source: www.ketso.com. Used with permission.

The Ketso workshop is based on a metaphorical analogy of a tree. The analogy provides a universal understanding of the elements of a tree during its growth. Some participants of previous Ketso workshops have agreed that the metaphorical use of a tree was excellent at cultivating a natural flow of discussion during the workshop from initial growth in the soil, to development of branches and leaves (Lombard, 2016). The centrepiece of the workshop is represented by the 'trunk'; the 'branches' represent themes, and the 'leaves' represent different ideas expressed by the participants.

Usually, the Ketso session starts with a warm-up question. The questions guiding the session theme are asked one by one. To answer each question, participants are allocated a specific time frame, for example, 10-15 minutes. Commonly, each 
session has four key stages (Figure 2). Each stage is associated with a different question and 'leaf' colour. To answer the question, participants write/draw the answer onto the 'leaf' and place it on a relevant 'branch' in order to co-create the themes.

At the first stage of the session, participants receive brown leaves, which represent soil on which ideas will grow. Participants could be asked the following questions: What works well? What do people already do that is effective? What is good about what we do now? After some time for generating ideas in silence, participants are asked to share their ideas one after another, one idea at a time.

[Insert Figure 2 near here.]

Figure 2 Stages of Ketso Session. Source: www.ketso.com. Used with permission.

The next stage is represented by green leaves and aims to generate new and creative ideas. Participants are encouraged to provide an answer to what could be done differently. The metaphor here is green shoots as newly growing ideas. If during the sharing stage participants mention similar ideas, they may be clustered on a branch. The third stage of the session uses grey leaves, which represent challenges and barriers. Thinking of a tree analogy, grey leaves represent clouds hiding the sun and getting in the way of what participants are aiming to achieve. At this stage, participants need to answer the following questions: What are the key barriers and challenges? What gets in the way or makes things difficult? To overcome these challenges, participants are invited to use green leaves to identify particular solutions to those problems. The last stage of the session relates to the coming out of the bright sunshine that drives growth and makes new ideas happen. Here the questions are focused on the goals which participants would like to achieve in the future. 
Ketso encourages participants to engage in productive co-creative dialogue. The method allows each participant to contribute to the discussion and engage in the cocreation of the content. One after each other participants present their ideas in a balanced environment where the shy participants are getting their voice heard and dominant participants have limited time to speak out their ideas. When participants see their ideas taking shape, alongside all the thoughts of the other participants, they are encouraged to move the leaves on the felt mat in front of them in order to see the commonalities and/or different points of view and to make new connections (Tippett \& How, 2011).

In previous research, Ketso has been used as a tool for data collection and as a tool for PhD students' training and development (Ketso, 2018; Njiraini, 2015). In this paper, we critically review Ketso as a co-creative community collaborative tool with stakeholders in the New Zealand Tourism For All project. Furthermore, we extend the use of the Ketso method and propose Ketso as a complementary data analysis tool.

\section{Ketso as data collection tool: The New Zealand Tourism For All project}

With the aim to creatively and collaboratively engage stakeholders to consider future solutions for achieving travel that is accessible for people with disabilities, the second and third authors facilitated a round-the-table planning session using Ketso with stakeholders from the tourism and access sectors in Christchurch in the South Island of New Zealand; a city being rebuilt following a series of devastating earthquakes. The aim of the Ketso session was to engage the stakeholders in a meaningful collaborative thinking process to consider and plan priorities and actions for accessible tourism development in the city and its wider region. Participants included four representatives from access organisations, one City Council representative, two representatives from major local tourist attractions, and one individual resident interested in the topic. The 
participants included those individuals with a disability and those without, but this was not a focus for their participation, and the question of their own disability was not raised with participants unless they themselves raised it.

The Ketso session lasted for approximately two hours, and the outcomes included key priorities for action, involving seven main themes/branches (Figure 3).

[Insert Figure 3 near here.]

Figure 3 Ketso session: The New Zealand Tourism For All project. Source: Authors' Image.

The seven themes were: communication; awareness but not yet understanding; innovation; celebration; quality; action; and promoting the return on investment in accessible tourism.

It should be noted that the Ketso method engages participants in co-creating and naming their own emergent 'themes' from the process. Overall, findings of the Ketso session revealed that participants felt there had been a positive growth (represented by green leaves) in awareness and public understanding of access needs and that there was a current climate for making a change and moving forward with planning for accessible tourism (represented by brown leaves). An unexpected outcome of the session was that few barriers were reported (represented by grey leaves) to achieving an accessible tourism plan for Christchurch, other than the low participation rate of stakeholders in the discussion about planning for accessibility. One of the objectives of the Ketso method is not to overly focus on barriers but to instead empower an innovative process for creative, collaborative thinking, and this may be a reason for the greater focus given to creative thoughts for future solutions, potentially fuelled by a shared positive attitude toward social change among the stakeholders who participated in the session. The key 
priorities for the future (represented by the yellow leaves) were the need for advertising campaigns that include people with disabilities; knowledge sharing for greater awareness of access needs; generation of pride from leading by example to make a difference (modelling excellent access design and 'telling the world'); and demonstrating and showcasing success in accessible tourism. Given the priorities identified by the participants to promote access champions and raise greater awareness of access needs, with the consent of participants, a final documentary, 'Take the Time', was developed and shared on social media and in various public venues to showcase the outcomes of the project, including footage of the Ketso session as the heart of the cocreated action plan (see: https://www.youtube.com/watch?v=xux0nKY2MQ0\&t=2s).

\section{Ketso as a supplementary analysis tool}

In this section, we would like to provide a critical overview on the combination of thematic analysis with the Ketso method to co-create the research findings of our tourism research (Wengel, McIntosh, \& Cockburn-Wootten, 2018). Thematic analysis is a flexible approach which can be applied across a range of epistemologies and research questions (Braun \& Clarke, 2006). It is an established tool for qualitative analysis which is based on searching through the collected data in order to find frequent patterns. The analysis is versatile and moves "beyond counting explicit words or phrases and focus[es] on identifying and describing both implicit and explicit ideas within the data, that is, themes" (Guest, MacQueen, \& Namey, 2012, p. 10). King (2004) argues that an advantage of thematic analysis is the opportunity to examine the perspectives of research participants, emphasising the similarities and differences, and generating unanticipated insights. Despite the advantages of thematic analysis, it is important to acknowledge its disadvantages. 
Some researchers critique thematic analysis by arguing that novice researchers may feel unsure of how to conduct a rigorous thematic analysis (Nowell, Norris, White, \& Moules, 2017). Holloway and Todres (2003) claim that themes derived from the research data, could lack coherence and be inconsistent. As in qualitative research, a researcher is an instrument of analysis who is collecting the data, analysing the data and making interpretation of the data regardless of methods used (Starks \& Trinidad, 2007), Nowell et al. (2017) call for more sophisticated tools and transparency in the process to conduct trustworthy thematic analysis.

To strengthen the analysis methods and overcome the limitations of the thematic analysis mentioned above we experimented with Ketso as a supplementary analysis tool in analysing data collected via unstructured in-depth interviews. The data originated from our multi-method qualitative study focusing on the relationships between farmers and volunteers working on their farms (as a part of World Wide Opportunities on Organic Farms (WWOOF) programme) we used an inductive approach to thematic analysis to interpret and elucidate meanings created by the participants. Initially, codes generated by thematic analysis were grouped into 12 common areas. Thereafter we experimented with Ketso as a supplementary analysis tool.

The first author conducted three one on one Ketso sessions to analyse the data. During the first session, she focused on codes relating to the relationships between farmers and their volunteers. As the result of the session, she rearranged the themes, and 12 common themes were confirmed. During the second Ketso session, the standard steps of Ketso were applied. The second session focused on identifying and confirming existing common areas as well as synthesising and refining the themes. As a result of the session, eight common themes emerged. After the third session, four key themes were determined and confirmed (Figure 4). 
[Insert Figure 4 near here.]

Figure 4 Final Ketso Session: Four Themes. Source: Authors’ Image.

As an outcome of the three Ketso sessions, the data generated by thematic analysis were rearranged into the common areas, and four final themes emerged: dirt, crossing the threshold, ideals, and ethics. Overall, the Ketso sessions helped us to achieve clarity within the common areas produced by thematic analysis. Furthermore, with Ketso as a supplementary analysis tool we gained more credibility in the analysis process and focused our attention on the key aspects of farmers and volunteers relationships and to define the four final themes.

\section{Discussion}

In the New Zealand Tourism For All project, Ketso was a tool used to creatively and collaboratively engage stakeholders from a range of sectors who might not otherwise share dialogue, such as the tourism and access sectors, in order to co-create an action plan for accessible tourism. As such, the process was crucial for enabling problemsolving around the complex, unconsidered and polysemous issues (Mitra \& Buzzanell, 2014). Participants reported gaining awareness and learning as well as being able to share knowledge as a result of being involved. On a wider level, the Ketso process fostered communication and relationship building and facilitated an opportunity to question existing practices. Despite reviewing different forms of stakeholder participation, including public hearings, advisory committees, surveys, focus groups, collaboration, work groups, among others, Byrd (2007) called for future studies to further consider the different forms and methods to achieve greater success in engaging stakeholders in the tourism planning process. Most previous tourism stakeholder 
analysis has been interview based (e.g., Aas, Paster, Stokes, Olsen, and Dewhirst (2005); Ernawati and Sugiarti (2005); Gillovic and McIntosh (2015)). Alternatively, this project sought a more collaborative approach in recognition of the fact that different forms of stakeholder participation do not all involve the same level of participation. Our objective was to actively engage stakeholders in an innovative process so that they feel empowered to think creatively about future solutions and inclusive to influence the decision. As Byrd (2007, p. 9) pointed out, "even if parties cannot resolve a particular issue, the process should be able to help them understand the goals and perspectives of others by fostering communication and build relationships".

Alternative planning tools such as community mapping and focus groups can be seen as limiting because they are said to impede mutual learning between participants; do not allow participants to engage in an active or meaningful manner; focus too much on problems and barriers hence reducing creative thinking; do not focus on future planning or creative thinking for new solutions; do not innovate or animate the process, nor plan for consensus as a mechanism to achieve development outcomes (McIntosh \& Cockburn-Wootten, 2016). As a method, Ketso does, however, require all participants to be available at the same time and location, and this might be considered a major limitation for stakeholder collaboration within a complex and diverse system such as tourism. We found this in our project, when only eight stakeholder participants were able to attend, despite over 200 invitations being sent out.

Previous research has also readily identified the problems of power, and issues of the 'silent majority' or 'most vocal' voice in tourism stakeholder collaborations (Aas et al., 2005; Tosun, 2000). The Ketso tool allowed all members of the session to contribute equally, rather than allowing certain voices to dominate the group; it is 
founded on inclusive and learning philosophies and systems thinking (see Tippett et al. (2007). A major advantage of the tool is, therefore, its ability to facilitate both individual ideas and group analysis toward a visual plan proposing a solution/action(s). And because Ketso parts are moveable (attached with Velcro), ideas can flow and be developed as they are raised and discussed among the participants. The main themes emerging from the workshop are inductively co-created by the participants themselves throughout the session. The final visual output helps participants understand complex relations; these are easily identifiable from the colour of the leaves in the output for example, where the most good is currently happening (i.e. most brown leaves) and where there is the best potential for growth (i.e. most green and yellow leaves). In short, the tool highlights the process of communication between different stakeholders to value their contribution, identifying the overall themes emerging from the group's thinking and their priority actions.

The attention to the inductive process of communication and knowledge sharing between different stakeholders maximises the value of their contribution and commitment to priority actions is a key benefit of the Ketso toolkit. Indeed, for this reason, McIntosh and Cockburn-Wootten (2016) have advocated it as a useful tool for enabling stakeholders to co-create methods for addressing social issues, such as accessibility and inclusion and proposing actions and solutions. Indeed, since disability is generally regarded as socially constructed (Oliver, 2013), this project highlighted that there remains an important need to reduce social barriers, and especially those barriers currently imposed by the tourism industry. To achieve this, it is argued that accessibility needs to become a fundamental part of the value chain among stakeholders, such as that proposed in the concept of universal design (Buhalis \& Darcy, 2010). As a tool, Ketso helps stakeholders to creatively understand the absences in their organisational sector 
and starts to get them ready for transformation. Ketso discussions make the absences and assumptions in the everyday worldviews of powerful stakeholders evident and open up an agency for changes to the tourism system. Significantly, it is the ontological framing behind the tool that allows stakeholders and academics to identify silences "to help us see openings, to provide a space of freedom and possibility" (Gibson-Graham, 2008, p. 619). Through providing space for creative thinking around accessibility and tourism, the Ketso process ensured that solutions shaped the kind of environment and tourism spaces that "we can imagine and create, ones in which we enact and construct" (Gibson-Graham, 2008, p. 619). These collaborative discussions allow the choice to think, act and consider different ways without the cynicism of critique or the restrictions of the past. By gathering together in one place, the stakeholders share tacit knowledge, overcome initial barriers from powerful stakeholders and gain solutions from people with direct experience of the issue.

In our second use of the method, we applied Ketso to ensure greater trustworthiness in the data analysis process; we decided to combine two analysis methods which mutually benefit each other (Guba, 1981), such as thematic analysis and Ketso. Two main benefits of thematic analysis are that it provides a systematic element to data analysis and provides an opportunity to understand the potential of any issue more widely (Marks \& Yardley, 2004). Although thematic analysis moves beyond counting words and focuses on identifying and describing implicit and explicit ideas (Namey, Guest, Thairu, \& Johnson, 2008), it could be hidden, subjective, and unable to address the complications of reflective research.

These limitations of thematic analysis could, however, be filled by further revisiting the data with Ketso methodology. Ketso enabled us to focus the thinking (Tippett \& How, 2011) and to see the deeper connections between different codes as 
common areas were co-created by the researcher. Using this tool allowed us to merge the common patterns into four key themes by following the logical path outlined in the Ketso methodology. With the help of this co-creative visual tool, we were able to get a deeper understanding of themes, to draw connections, to prioritise themes, and to find patterns which were previously overlooked. Ketso sessions helped us to achieve clarification and to define four final themes by focusing the attention on the key aspects and allowing the researcher to co-create the themes.

Despite the advantages of the combination of Ketso and thematic analysis, there still remain limitations. The main limitations of the Ketso method is the necessity of a special kit, skilled facilitator as well as the space and time for running the session. In previous studies, some research participants found Ketso to be a difficult and unsettling concept because of its inductive nature (McIntosh \& Cockburn-Wootten, 2016). For the first author, the difficulty was to facilitate a one-on-one session for herself as a lot of reflexive thoughts intervened on the Ketso process. Such as, "Am I a facilitator now?" or "What would be the next step of the Ketso process?" To overcome this difficulty, we would recommend that the Ketso session is facilitated by another person. In this way, a researcher would be guided through the Ketso session by the facilitator and therefore will be able to better concentrate on the context of the session, and focus on synthesising the themes.

\section{Conclusions}

Effective social impact that makes a difference to our societies requires a change in research design, theoretical orientation and activities that increase participation and engagement. In this article, we presented Ketso as a complementary qualitative tool which could enhance this type of research design, create opportunities for richer 
understandings, new knowledge across diverse stakeholders and provide reciprocal learning opportunities. Aligned with Ind and Coates's (2013) understanding of the cocreation concept, Ketso offers researchers, participants and wider stakeholders the space, time and process to generate solutions, build capacity, and create value together. Furthermore, we contribute by providing guidance toward using Ketso to complement other qualitative data analysis methods. For example, Braun and Clarke (2006) established thematic analysis as a foundational method for qualitative data analysis, and although it has been widely used across social sciences, many researchers criticise it for the simplicity and its lack of coherence. Our research findings suggest that a combination of Ketso and thematic analysis can potentially achieve richer saturation across the data which increases the accountability and verification of the research findings and analysis. In our experience combining Ketso and thematic analysis enables a transactive process of data analysis to occur. This provides opportunities for scholars, especially those investigating new topics or issues that participants may have difficulty in expressing their experiences, for both explicit and tacit knowledge to be highlighted.

For tourism researchers dealing with a diverse system involving organisations, NGOs, activists and communities, Ketso contributes by offering opportunities for involving both individual and group reciprocal learning and engagement. Ketso also contributes to the wider academic field by providing a collaborative tool to enable communities to come together, overcome silos and think - enabling them to identify problems and then move towards creating innovative solutions to addresses issues they have identified together. As a tool, Kesto illustrates a co-creative transactive method that can be used by tourism researchers who are theoretically aligned to work with and within communities to co-create change and overcome traditional academic top-down approaches to research. Ketso provides opportunities for researchers to overcome these 
silos and work differently, to share experiences, problems, expertise, all in order to tackle particular issues identified by the community - not the academic. In doing so, as illustrated in the New Zealand Tourism For All research, Ketso facilitates individuals and groups' thinking around identifying problems rather than concentrating on symptoms to then identify solutions.

As a co-creative method, Ketso fits into a range of collaborative, action-oriented transformative research and engagement philosophies that encourage individuals to become involved in thinking about innovative solutions to tackle issues and create positive social impact. These alternative narratives and actions that inductively emerge during the Ketso process help create an understanding for groups of the choices available for tackling the issue. This collaborative framework and the Ketso tool provide value-creation to all involved in the research - not just the more powerful or dominate individuals in the project. 


\section{References}

Aas, J. A., Paster, B. J., Stokes, L. N., Olsen, I., \& Dewhirst, F. E. (2005). Defining the Normal Bacterial Flora of the Oral Cavity. Journal of Clinical Microbiology, 43(11), 5721-5732. 10.1128/jcm.43.11.5721-5732.2005

Baker, T. A., \& Wang, C. C. (2006). Photovoice: Use of a Participatory Action Research Method to Explore the Chronic Pain Experience in Older Adults. Qualitative Health Research, 16(10), 1405-1413. 10.1177/1049732306294118

Banks, M. (2007). Using visual data in qualitative research. Los Angeles, CA: SAGE.

Barry, K. (2017). Diagramming: A creative methodology for tourist studies. Tourist Studies, 17(3), 328-346. 10.1177/1468797616680852

Bates, J. S. (2016). Ketso: A new tool for extension professionals. Journal of extension, $54(1), 1-4$.

Bean, G., \& Baber, K. M. (2011). Connect: An Effective Community-Based Youth Suicide Prevention Program. Suicide and Life-Threatening Behavior, 41(1), 8797. doi:10.1111/j.1943-278X.2010.00006.x

Bigby, C., Frawley, P., \& Ramcharan, P. (2014). Conceptualizing Inclusive Research with People with Intellectual Disability. Journal of Applied Research in Intellectual Disabilities, 27(1), 3-12. doi:10.1111/jar.12083

Boaz, A., Fitzpatrick, S., \& Shaw, B. (2009). Assessing the impact of research on policy: A literature review. Science and Public Policy, 36(4), 255-270. $10.3152 / 030234209 X 436545$

Braun, V., \& Clarke, V. (2006). Using thematic analysis in psychology. Qualitative Research in Psychology, 3(2), 77-101. http://dx.doi.org/10.1191/1478088706qp063oa

Buhalis, P. D., \& Darcy, S. (2010). Accessible Tourism: Concepts and Issues: Channel View Publications.

Buzan, T., \& Buzan, B. (2006). The mind map book. Harlow, United Kingdom: BBC Active.

Byrd, E. T. (2007). Stakeholders in sustainable tourism development and their roles: applying stakeholder theory to sustainable tourism development. Tourism Review, 62(2), 6-13. doi:10.1108/16605370780000309

Campos, A. C., Mendes, J., Valle, P. O. d., \& Scott, N. (2018). Co-creation of tourist experiences: a literature review. Current Issues in Tourism, 21(4), 369-400. $10.1080 / 13683500.2015 .1081158$

Canosa, A., Wilson, E., \& Graham, A. (2017). Empowering young people through participatory film: a postmethodological approach. Current Issues in Tourism, 20(8), 894-907. 10.1080/13683500.2016.1179270

Cockburn-Wootten, C., McIntosh, A. J., Smith, K., \& Jefferies, S. (2018). Communicating across tourism silos for inclusive sustainable partnerships. Journal of Sustainable Tourism, 1-16. 10.1080/09669582.2018.1476519

Cook, T., Atkin, H., \& Wilcockson, J. (2017). Participatory Research Into Inclusive Practice: Improving Services for People With Long Term Neurological Conditions. 2017, 19(1) 10.17169/fqs-19.1.2667

Dale, A., \& Newman, L. (2005). Sustainable development, education and literacy. International Journal of Sustainability in Higher Education, 6(4), 351-362. doi:10.1108/14676370510623847

De Bono, E. (2009). De Bono's thinking course. Harlow, United Kingdom: BBC Active.

Dredge, D. (2006). Networks, Conflict and Collaborative Communities. Journal of Sustainable Tourism, 14(6), 562-581. 10.2167/jost567.0 
Dredge, D., \& Phi, G. (2018). Critical issues in tourism co-creation. Tourism Recreation Research

Ernawati, D. B., \& Sugiarti, R. (2005). Developing an Accessible Tourist Destination Model for People with Disability in Indonesia. Tourism Recreation Research, 30(3), 103-106. 10.1080/02508281.2005.11081492

Espeso-Molinero, P., Carlisle, S., \& Pastor-Alfonso, M. J. (2016). Knowledge dialogue through Indigenous tourism product design: a collaborative research process with the Lacandon of Chiapas, Mexico. Journal of Sustainable Tourism, 24(89), 1331-1349. 10.1080/09669582.2016.1193188

Fals Borda, O. (2001). Partipatory (action) research in social theory: Orgins and challenges. In P. Reason \& H. Bradbury (Eds.), Handbook of action research participative inquiry \& practice (pp. 27-47). London, UK: Sage.

Galvagno, M., \& Dalli, D. (2014). Theory of value co-creation: A systematic literature review. Managing Service Quality: An International Journal, 24(6), 643-683. 10.1108/MSQ-09-2013-0187

Gardner, H. (1999). Intelligence reframed: Multiple intelligences for the 21st century. New York, NY: Basic Books.

Gauntlett, D., \& Awah, F. (2012). Action-based visual and creative methods in social research. In I. Heywood \& B. Sandwell (Eds.), The handbook of visual culture. Oxford, United Kingdom: Berg Publishers.

Gibson-Graham, J. K. (2008). Diverse economies: performative practices for 'other worlds'. Progress in Human Geography, 32(5), 613-632. $10.1177 / 0309132508090821$

Gillovic, B., \& McIntosh, A. (2015). Stakeholder perspectives of the future of accessible tourism in New Zealand. Journal of Tourism Futures, 1(3), 223-239. doi:10.1108/JTF-04-2015-0013

Gillovic, B., McIntosh, A., Darcy, S., \& Cockburn-Wootten, C. (2018). Enabling the language of accessible tourism. Journal of Sustainable Tourism, 26(4), 615-630. 10.1080/09669582.2017.1377209

Greenhalgh, T., Jackson, C., Shaw, S., \& Janamian, T. (2016). Achieving Research Impact Through Co-creation in Community-Based Health Services: Literature Review and Case Study. The Milbank Quarterly, 94(2), 392-429. 10.1111/14680009.12197

Guba, E. G. (1981). Criteria for assessing the trustworthiness of naturalistic inquiries. Educational Communication and Technology, 29(2), 75-91. http://dx.doi.org/10.1007/BF02766777

Guest, G., MacQueen, K. M., \& Namey, E. E. (2012). Applied thematic analysis. Los Angeles, CA: SAGE.

Hales, R., Dredge, D., Higgins-Desbiolles, F., \& Jamal, T. (2018). Academic Activism in Tourism Studies: Critical Narratives from Four Researchers. Tourism Analysis, 23(2), 189-199. 10.3727/108354218X15210313504544

Harwell, M. (2011). Research design in qualitative/quantitative/mixed methods. In C. F. Conrad \& R. C. Serlin (Eds.), The Sage Handbook for Research in Education: Pursuing ideas as the keystone of exemplary inquiry (pp. 147-164). Thousand Oaks, CA.: Sage.

Haseman, B. (2006). A manifesto for performative research. Media International Australia incorporating Culture and Policy, 118(1), 98-106. 10.1177/1329878X0611800113

Hill, S. (2016). Assessing (for) impact: Future assessment of the societal impact of research. Palgrave Communications, 2, 16073. 10.1057/palcomms.2016.73 
Holloway, I., \& Todres, L. (2003). The status of method: Flexibility, consistency and coherence (Vol. 3, pp. 345-357).

Horowitz, C. R., Robinson, M., \& Seifer, S. (2009). Community-based participatory research from the margin to the mainstream: are researchers prepared? Circulation, $119(19)$

Ind, N. \& Coates, N. (2013) The meanings of co-creation, European Business Review, 25(1), 86-95.

Ji, M., \& King, B. (2018). Explaining the embodied hospitality experience with ZMET. International Journal of Contemporary Hospitality Management, 30(11), 34423461. 10.1108/IJCHM-10-2017-0709

Ketso. (2018). Research-Ketso as a method. Retrieved from https://ketso.com/examples-case-studies/case-studies/research\#DTC

King, N. (2004). Using templates in the thematic analysis of text. In C. Cassell \& G. Symon (Eds.), Essential guide to qualitative methods in organizational research (pp. 257-270). London Sage.

Kolb, D. A. (1984). Experiential learning: Experience as the source of learning and development. Englewood Cliffs, NJ: Prentice-Hall.

Lombard, M. (2016). Rights to the City. Retrieved from http://www.ketso.com/examples-case-studies/case-studies/research

Marks, D., \& Yardley, L. (2004). Research methods for clinical and health psychology. Thousand Oaks, CA: SAGE.

McIntosh, A., \& Cockburn-Wootten, C. (2018). Refugee-focused service providers: improving the welcome in New Zealand. The Service Industries Journal, 1-16. 10.1080/02642069.2018.1472243

McIntosh, A. J., \& Cockburn-Wootten, C. (2016). Using Ketso for engaged tourism scholarship. Annals of Tourism Research, 56, 148-151. http://dx.doi.org/10.1016/j.annals.2015.11.003

Mitra, R., \& Buzzanell, P. M. (2014). Introduction: Organizing/Communicating Sustainably. Management Communication Quarterly, 29(1), 130-134. $10.1177 / 0893318914563573$

Namey, E., Guest, G., Thairu, L., \& Johnson, L. (2008). Data reduction techniques for large qualitative data sets. In G. Guest \& K. M. MacQueen (Eds.), Handbook for team-based qualitative research. Lanham, MD: Altamira.

Njiraini, N. N. K. (2015). Exploring the importance of critical thinking in creating capabilities for self-reliance in international community development: A Kenyan context. University of Glasgow, Glasgow.

Nowell, L. S., Norris, J. M., White, D. E., \& Moules, N. J. (2017). Thematic analysis: Striving to meet the trustworthiness criteria. International Journal of Qualitative Methods, 16(1), 1609406917733847. 10.1177/1609406917733847

Nowotny, H., Scott, P., \& Gibbons, M. (2003). Introduction: 'Mode 2' revisited: The new production of knowledge. Minerva, 41(3), 179-194. 10.1023/a:1025505528250

Oliver, M. (2013). The social model of disability: Thirty years on. Disability \& Society, 28(7), 1024-1026. 10.1080/09687599.2013.818773

Pink, S. (2012). Advances in Visual Methodology: SAGE Publications.

Potts, T. D., \& Harrill, R. (1998). Enhancing communities for sustainability: A travel ecology approach. Tourism Analysis, 3(3/4), 133-142.

Pritchard, A., Morgan, N., \& Ateljevic, I. (2011). Hopeful tourism: A new transformative perspective. Annals of Tourism Research, 38(3), 941-963. https://doi.org/10.1016/j.annals.2011.01.004 
Ramanayake, U., McIntosh, A., \& Cockburn-Wootten, C. (2018). Loss and travel: a review of literature and current understandings. Anatolia, 29(1), 74-83. 10.1080/13032917.2017.1387162

Reed, M. S. (2018). The research impact handbook (2nd ed.): Huntly, Aberdeenshire.

Ren, C., Pritchard, A., \& Morgan, N. (2010). Constructing tourism research: A Critical Inquiry. Annals of Tourism Research, 37(4), 885-904. https://doi.org/10.1016/j.annals.2009.11.006

Rydzik, A., Pritchard, A., Morgan, N., \& Sedgley, D. (2013). The potential of artsbased transformative research. Annals of Tourism Research, 40, 283-305. https://doi.org/10.1016/j.annals.2012.09.006

Salazar, N. B. (2012). Tourism imaginaries: A conceptual approach. Annals of Tourism Research, 39(2), 863-882. https://doi.org/10.1016/j.annals.2011.10.004

Scarles, C. (2010). Where words fail, visuals ignite: Opportunities for Visual Autoethnography in Tourism Research. Annals of Tourism Research, 37(4), 905-926. https://doi.org/10.1016/j.annals.2010.02.001

Sedgley, D., Pritchard, A., \& Morgan, N. (2011). Tourism and ageing: A transformative research agenda. Annals of Tourism Research, 38(2), 422-436. https://doi.org/10.1016/j.annals.2010.09.002

Singh, T. V. (2012). Critical debates in tourism. Bristol, UK: Channel View Publications.

Starks, H., \& Trinidad, S. B. (2007). Choose your method: A comparison of phenomenology, discourse analysis, and grounded theory Periodical(10), 1372.

Retrieved from

http://ezproxy.leedsbeckett.ac.uk/login?url=http://search.ebscohost.com/login.as px?direct $=$ true $\& \mathrm{db}=$ edsbl\&AN $=\mathrm{RN} 219574810 \&$ site $=$ eds-live \&scope $=$ site

Tippett, J. (2013). Creativity and learning - Participatory planning and the coproduction of local knowledge. Town \& Country Planning, 82(10), 439-442.

Tippett, J., Handley, J. F., \& Ravetz, J. (2007). Meeting the challenges of sustainable development - A conceptual appraisal of a new methodology for participatory ecological planning. Progress in Planning, 67(1), 9-98. http://dx.doi.org/10.1016/j.progress.2006.12.004

Tippett, J., \& How, F. (2011). Ketso guide. Manchester, United Kingdom: Ketso

Tosun, C. (2000). Limits to community participation in the tourism development process in developing countries. Tourism Management, 21(6), 613-633. https://doi.org/10.1016/S0261-5177(00)00009-1

van der Vaart, G., van Hoven, B., \& Huigen, P. P. P. (2018). Creative and Arts-Based Research Methods in Academic Research. Lessons from a Participatory Research Project in the Netherlands. 2018, 19(2) 10.17169/fqs-19.2.2961

Wengel, Y., McIntosh, A., \& Cockburn-Wootten, C. (2018). Tourism and 'dirt': A case study of WWOOF farms in New Zealand. Journal of Hospitality and Tourism Management, 35, 46-55. https://doi.org/10.1016/j.jhtm.2018.03.001

Wengel, Y., McIntosh, A. J., \& Cockburn-Wootten, C. (2016). Constructing tourism realities through LEGO ${ }^{\circledR}$ SERIOUS PLAY ${ }^{\circledR}$. Annals of Tourism Research, 56, 161-163. http://dx.doi.org/10.1016/j.annals.2015.11.012

Whitworth, A., Torras I Calvo, M. C., Moss, B., Amlesom Kifle, N., \& Blåsternes, T. (2014). Changing libraries: Facilitating self-reflection and action research on organizational change in academic libraries. New Review of Academic Librarianship, 20(2), 251-274. 10.1080/13614533.2014.912989 
Willson, G. B., McIntosh, A. J., \& Zahra, A. L. (2013). Tourism and spirituality: A phenomenological analysis. Annals of Tourism Research, 42, 150-168. https://doi.org/10.1016/j.annals.2013.01.016

Zaltman, G., \& Coulter, R. H. (1995). Seeing the voice of the customer: Metaphorbased advertising research. Journal of Advertising Research, 35(4), 35-51. 